\title{
Developing an Instrument to Measure Maternal Knowledge and Attitude of Oral Health on Children Under 3 Years
}

\author{
Netty Suryanti ${ }^{1}$ Arlette Suzy Setiawan ${ }^{2}$ \\ ${ }^{1}$ Department of Community Dentistry, Faculty of Dentistry, \\ Universitas Padjadjaran, Bandung, Indonesia \\ 2Department of Pediatric Dentistry, Faculty of Dentistry, Universitas \\ Padjadjaran, Bandung, Indonesia \\ Eur J Dent 2021;15:624-629.
}

Address for correspondence Arlette Suzy Setiawan, drg., Sp.KGA(K), M.Si, Department of Pediatric Dentisty, Faculty of Dentistry, Universitas Padjadjaran, Bandung, Indonesia (e-mail: arlette.puspa@fkg.unpad.ac.id).

\begin{abstract}
Keywords

- knowledge

- attitude

- maternal

- oral health

- children under three
\end{abstract}

Objective Parental knowledge, belief, and attitude about oral health affect children's dental cleaning behavior. Further research on maternal knowledge and attitude about early-age children's oral health has been suggested to identify factors related to pediatric dental and oral health. For that purpose, a measurement instrument is needed. The research aimed to develop an instrument to measure maternal knowledge and attitude about under 3-year-old children's oral health.

Materials and Methods Using a validity-based approach, we held a series of basic consultation (workshops and interviews) to identify the conceptually different domains. Instrument items were derived from relevant theories. Cognitive interviews were conducted to ensure that the items were properly understood. The items were first tested among the population calibration samples $(n=150)$. All instrument items were analyzed for reliability and validity.

Results In total, 15 items were derived from Bloom's theory of learning and were developed for the knowledge instrument, while 10 others were developed for the attitude instrument. The reliability analysis yielded Cronbach's $\alpha$ scores of 0.620 for the knowledge instrument and 0.565 for the attitude instrument. All items were considered valid based on Pearson's correlation test results.

Conclusion The instruments on maternal knowledge and attitude about under 3-year-old children's oral health consisted of three dimensions, respectively. Both instruments have been tested and analyzed and therefore are applicable for use.

\section{Introduction}

Some theories of attitude, including the Health Belief Model and the Theory of Reason Action, have confirmed the central role of knowledge and attitude in describing behavioral change. ${ }^{1,2}$ These aspects are specifically highlighted in assessing the role of parental knowledge and attitude about their children's health. Parents play a crucial role in giving their children the information and support needed to live a healthy life. ${ }^{3}$

DOI https://doi.org/

$10.1055 / \mathrm{s}-0041-1725579$

ISSN 1305-7456.
Parental knowledge, belief, and attitude about oral health affect children's dental cleaning behavior. ${ }^{4}$ Furthermore, parental attitude brings a significant positive impact on children's dental caries condition and gingival health., ${ }^{5,6}$ Maternal role in promoting their children's oral habits and health has been emphasized. ${ }^{7-9}$ Despite possible shift of role and responsibility in their family, ${ }^{10}$ mothers still play an essential role in shaping their children's lifestyle, particularly their oral health.,9 (c) 2021. European Journal of Dentistry.

This is an open access article published by Thieme under the terms of the Creative Commons Attribution-NonDerivative-NonCommercial-License, permitting copying and reproduction so long as the original work is given appropriate credit. Contents may not be used for commercial purposes, or adapted, remixed, transformed or built upon. (https://creativecommons.org/licenses/by-nc-nd/4.0/).

Thieme Medical and Scientific Publishers Pvt. Ltd. A-12, 2nd Floor, Sector 2, Noida-201301 UP, India 
To identify the factors related to children's oral health, further research on maternal knowledge and attitude about dental and oral health in early age children has been suggested. ${ }^{11}$ A body of research has been conducted to study the vital impact of parental knowledge and attitude about their oral health on preschool children's oral health. ${ }^{12,13}$ Similar studies have also been conducted on school-age children. ${ }^{14,15}$ Information from these studies is important, especially in societies where mothers play a crucial role in raising children. Currently, several instruments to measure maternal knowledge and attitude about oral health in children have been developed though still very general. Unfortunately, a similar tool that focuses on early-age children (under 3 years) has yet to be developed. This study aimed to develop a measurement instrument to assess maternal knowledge and attitude about oral health in children under 3 years.

\section{Materials and Methods}

This research attempted to design a measurement instrument using a descriptive approach and a survey to obtain data from 150 mothers who live in Bandung Municipality, Indonesia and have children under 3 years.

\section{Measurement Instrument}

The measurement instrument developed in this research was designed to obtain information about maternal knowledge and attitude about oral health in children under three (-Table 1). The development of the instrument followed the following steps: measurement instrument design, content validity, formulation of psychometric characteristics, namely their validity and reliability. Items concerning knowledge were derived from Bloom's theory, based on which knowledge can be broken down into three dimensions: translation, interpretation, and extrapolation. ${ }^{16}$ The items for the attitude instrument were derived from the cognitive-affective-conative behavioral model. ${ }^{17}$

\section{Assessment}

The instrument consists of 25 items and were grouped into knowledge (15 items) and attitude (10 items). The knowledge instrument used a true-false design ( - Table 2 ), whereas the attitude instrument used the following Likert 5-point scale: strongly agree (SA), agree (A), neutral (N), disagree (D), and strongly disagree (SD) (-Table $\mathbf{3}$ ). The instruments were thus designed to achieve the instrument's aim, namely practicality and time efficiency. In the knowledge instrument, scores are 1 for a correct answer and 0 for a wrong answer. The total score for the respondent knowledge was built by adding 15 items (ranging from 0 to 15 ). A higher score indicates a more positive knowledge. In the attitude instrument, for item number $1,5,9$, and 10 , the scores are as follows $S A=$ $5, A=4, N=3, D=2$, and $S D=1$. As for item number $2,3,4,6$, 7 , and 8 , the scores are reverse as follows $S A=1, A=2, n=3$, $\mathrm{D}=4$, and $\mathrm{SD}=5$. The total score for the respondent attitude was built by adding items (ranging from 10 to 50). A higher score indicates a more positive attitude.

\section{Statistical Analysis}

\section{Item Analysis}

Item analysis is required to determine whether the items in the instrument have been well formulated. In this research, item analysis was done by calculating each item's distinguishing feature based on the item-total correlation. In calculating distinguishing feature, item-total correlation was used to determine the consistency between an item's score and the total score. Consistency was determined based on the coefficient of correlation between an item and the total score. Since each item in this research was scored based on Likert scale, correlation coefficient was obtained by using Pearson's correlation formula:

Where:

$$
r_{x x}=\frac{\left(\sum X_{1} X_{2}\right)-\left(\overline{X_{1}}\right)\left(\overline{X_{2}}\right)}{\left(\sigma_{X 1}\right)\left(\sigma_{X 2}\right)}
$$

$X_{1}=$ total first set score

$X_{2}=$ total second set score

$\bar{X}_{1}=$ average $X_{1}$ score

$\bar{X}_{2}=$ average $X_{2}$ score

$\sigma_{x 1}=$ standard deviation of $X_{1}$

$\sigma_{x 2}=$ standard deviation of $X_{2}$

Table 1 Maternal knowledge and attitude construct

\begin{tabular}{|c|c|c|c|}
\hline Dimension & Operating definition & Indicator & Items \\
\hline \multicolumn{4}{|c|}{ Knowledge instrument } \\
\hline Translation & Ability to understand a nonliteral statement & $\begin{array}{l}\text { Mention } \\
\text { differentiate }\end{array}$ & 2.3.4.5.12 \\
\hline Interpretation & Ability to recognize information & Exemplify & 1.6.7.8.14 \\
\hline Extrapolation & Ability to conclude information & Use a concept & 9. 10.11 .15 \\
\hline \multicolumn{4}{|l|}{ Attitude instrument } \\
\hline Cognitive aspect & $\begin{array}{l}\text { The aspect of recognizing thought, that is, knowledge and } \\
\text { belief, based on information related to dental health }\end{array}$ & $\begin{array}{l}\text { Knowledge about disease } \\
\text { Knowledge about healthy } \\
\text { life }\end{array}$ & 1.8. 10 \\
\hline Affective aspect & The aspect of emotion related to dental health & Attitude toward disease & 2.3 .5 \\
\hline Conative aspect & The aspect of attitude involving the tendency to act & Attitude toward disease & 4.6.7.9 \\
\hline
\end{tabular}


Table 2 Items in the knowledge instrument

\begin{tabular}{|c|c|c|c|}
\hline No. & List of statements & True & False \\
\hline 1 & $\begin{array}{l}\text { The ideal toothbrushing frequency for children between } 2 \text { and } 3 \text { years of age is once a } \\
\text { day or whenever they are willing. }\end{array}$ & & \\
\hline 2 & $\begin{array}{l}\text { The ideal toothbrushing time for children between } 2 \text { and } 3 \text { years of age is during } \\
\text { morning and afternoon baths. }\end{array}$ & & \\
\hline 3 & $\begin{array}{l}\text { High frequency of snacking on foods and drinks with high sugar content (chips, } \\
\text { biscuits, sweets, chocolate, and boxed/bottled drinks such as juice/soda/tea) among } \\
\text { children will affect their health and growth. }\end{array}$ & & \\
\hline 4 & $\begin{array}{l}\text { The toothbrushing method for children between } 2 \text { and } 3 \text { years of age is to brush the } \\
\text { entire surface of their upper and lower teeth with repeated backward and forward } \\
\text { movements. }\end{array}$ & & \\
\hline 5 & $\begin{array}{l}\text { Mothers must guide their children when they are brushing their teeth because, with } \\
\text { their still limited motoric skills, children at such an age have yet to develop ideal } \\
\text { brushing movements. }\end{array}$ & & \\
\hline 6 & $\begin{array}{l}\text { To brush your teeth, you must use fluoride toothpaste, placing it along the bristles' } \\
\text { top surface. }\end{array}$ & & \\
\hline 7 & It is recommended to give children foods that they like. & & \\
\hline 8 & $\begin{array}{l}\text { After brushing their teeth, children must rinse their mouth to remove the remaining } \\
\text { toothpaste from their mouth. }\end{array}$ & & \\
\hline 9 & Frequent snacking (on sugary foods) will accelerate dental cavity formation. & & \\
\hline 10 & Oral health will not significantly affect children's overall health and growth. & & \\
\hline 11 & $\begin{array}{l}\text { Visiting a dentist regularly every } 6 \text { months is important to prevent dental decay } \\
\text { despite the absence of toothache. }\end{array}$ & & \\
\hline 12 & $\begin{array}{l}\text { In preventing dental decay, it does not matter how often my child eats as long as } \\
\text { there is no sugar in his/her food. }\end{array}$ & & \\
\hline 13 & Frequent toothbrushing can prevent dental decay/cavity. & & \\
\hline 14 & $\begin{array}{l}\text { Dental cavity with no pain in children between } 2 \text { and } 3 \text { years of age is not a source } \\
\text { of worry because their deciduous teeth will be replaced with permanent teeth when } \\
\text { they grow up. }\end{array}$ & & \\
\hline 15 & Dental cavities in children can be prevented only by frequent toothbrushing. & & \\
\hline
\end{tabular}

Table 3 Items in the attitude instrument

\begin{tabular}{|c|c|c|c|c|c|c|}
\hline \multirow[t]{2}{*}{ No. } & \multirow[t]{2}{*}{ List of statements } & \multicolumn{5}{|c|}{ Possible answers } \\
\hline & & SA & A & $\mathrm{N}$ & D & SD \\
\hline 1 & $\begin{array}{l}\text { It is important to maintain oral health by brushing teeth twice a day from } \\
\text { the age of } 2 \text { to } 3 .\end{array}$ & & & & & \\
\hline 2 & $\begin{array}{l}\text { In my opinion, children between } 2 \text { or } 3 \text { years of age should not always be } \\
\text { attended when they are brushing their teeth. }\end{array}$ & & & & & \\
\hline 3 & In my opinion, types of food will not affect my child's oral health. & & & & & \\
\hline 4 & I let my child have snacks when he or she refuses to eat. & & & & & \\
\hline 5 & $\begin{array}{l}\text { It is recommended to brush teeth every day after breakfast and at night } \\
\text { before sleep. }\end{array}$ & & & & & \\
\hline 6 & $\begin{array}{l}\text { For mothers, letting their children eat foods of their choice is better than } \\
\text { letting them eat nothing at all. }\end{array}$ & & & & & \\
\hline 7 & $\begin{array}{l}\text { I seldom pay attention to my child's dental condition if there is no } \\
\text { complaint. }\end{array}$ & & & & & \\
\hline 8 & It is not important for my child to drink milk once a day. & & & & & \\
\hline 9 & $\begin{array}{l}\text { I give my child a balanced diet (rice, meat/fish, vegetable, fruit, and milk) } \\
\text { every day. }\end{array}$ & & & & & \\
\hline 10 & Dental pain will affect children's growth. & & & & & \\
\hline
\end{tabular}

Abbreviations: A, agree; N, neutral; D, disagree; SA, strongly agree; SD, strongly disagree. 


\section{Validity}

Validity indicates whether or not a research instrument can measure the object it has been designed to measure. The higher its validity, the more accurate the instrument in measuring its object. Before being put into trial, the instrument had been assessed by three dentists from the Department of Pediatric Dentistry, a dentist from the Department of Community Dentistry, and a psychologist from the Department of Social Psychology. To assess the instrument's validity, a test was conducted by using Pearson's bivariate correlation (Pearson's product-moment correlation) in SPSS 25.0 software, by which the score of each item was correlated with the total score. The total score was the total sum of all item scores. Instrument items that correlate significantly with the total score would indicate their plausibility to support and illustrate what they had been designed to express (valid). If r-count was greater than or equal to $(\geq)$ r-table (two-tailed test with sig. 0.05 ), the instrument or the instrument items correlated significantly with the total score (valid). ${ }^{18,19}$

\section{Reliability}

The internal consistency method was used to test the instrument's reliability. A test was conducted by measuring the different items of the same instrument. The instrument has only one measurement version. Therefore, the method was well suited for the test.

Conceptually, the instrument would not result in a total score. Instead, it would yield the total score for each dimension. Thus, reliability coefficient was to be calculated as per dimension. Considering that each dimension had only a few items (10 items per dimension), reliability coefficient was calculated by using the following $\alpha$ coefficient equation:

Where:

$$
\begin{array}{ll}
r=\frac{k}{k-1} & \left(1-\frac{\left.\sum \sigma^{2} i\right)}{\sigma_{x}^{2}}\right. \\
\text { Where : } & =\text { number of item } \\
k & =\text { Variance in every item } \\
\sigma i^{2} & =\text { number of every variance } \\
\sum \sigma_{i}^{2} & =\text { item variance } \\
\sigma_{x}^{2} &
\end{array}
$$

\section{Results}

\section{Item Analysis}

The distinguishing feature of each item was calculated via intercorrelation Pearson's product-moment correlation) by using SPSS 25.0 software, and the results are presented in - Table 4.

\section{Reliability}

The reliability test results yielded a Cronbach's $\alpha$ score of 0.620 for the knowledge instrument and 0.565 for the attitude instrument. - Table 5 below shows the Cronbach's $\alpha$ scores yielded if certain items were deleted.

\section{Validity}

As shown in - Table 6, Pearson's correlation test yielded valid results for all items.

\section{Discussion}

In this research, we attempted to generate a concept, as well as develop and test a new set of instruments to measure maternal knowledge and attitude about oral health in children under three. We developed two instruments, that is, knowledge instrument and attitude instruments, consisting of 15 and 10 instrument items, respectively (-Tables 2 and $\mathbf{3}$ ). A measurement instrument is considered solid if it meets these three requirements: well-formulated items, reliability, and validity. A crucial step required in developing a measurement instrument is item analysis. The term refers to the statistical cal-

\begin{tabular}{|c|c|c|c|}
\hline Dimension & Item & $R$ & Correlation \\
\hline \multicolumn{4}{|l|}{ Knowledge } \\
\hline \multirow[t]{5}{*}{ Translation } & 2 & 0.493 & Moderate \\
\hline & 3 & 0.307 & Low \\
\hline & 4 & 0.464 & Moderate \\
\hline & 5 & 0.060 & Very low \\
\hline & 12 & 0.042 & Very low \\
\hline \multirow[t]{5}{*}{ Interpretation } & 1 & 0.479 & Moderate \\
\hline & 6 & 0.494 & Moderate \\
\hline & 7 & 0.441 & Moderate \\
\hline & 8 & 0.075 & Very low \\
\hline & 14 & 0.441 & Moderate \\
\hline \multirow[t]{4}{*}{ Extrapolation } & 9 & 0.179 & Very low \\
\hline & 10 & 0.414 & Moderate \\
\hline & 11 & 0.253 & Low \\
\hline & 15 & 0.187 & Very Low \\
\hline \multicolumn{4}{|l|}{ Attitude } \\
\hline \multirow[t]{3}{*}{ Cognitive aspect } & 1 & 0.365 & Low \\
\hline & 8 & 0.321 & Low \\
\hline & 10 & 0.117 & Very Low \\
\hline \multirow[t]{3}{*}{ Affective aspect } & 2 & 0.405 & Medium \\
\hline & 3 & 0.309 & Low \\
\hline & 5 & 0.236 & Low \\
\hline \multirow[t]{4}{*}{ Conative aspect } & 4 & 0.547 & Moderate \\
\hline & 6 & 0.510 & Moderate \\
\hline & 7 & 0.409 & Moderate \\
\hline & 9 & 0.021 & Very low \\
\hline
\end{tabular}
culation and test performed on individual item scores to obtain reliability and validity. ${ }^{20}$ The item analysis results showed that the highest-scoring items still fell under the "medium correlation" category. No items showed a strong correlation.

Table 4 Item analysis 
Table 5 Measurement instrument reliability

\begin{tabular}{|c|c|c|c|}
\hline Dimension & Item & $\begin{array}{l}\text { Cronbach's } \alpha \text { if item } \\
\text { deleted }\end{array}$ & Criteria \\
\hline \multicolumn{4}{|c|}{ Knowledge instrument } \\
\hline \multirow[t]{5}{*}{ Translation } & 2 & 0.586 & $\begin{array}{l}\text { Quite } \\
\text { reliable }\end{array}$ \\
\hline & 3 & 0.611 & Reliable \\
\hline & 4 & 0.590 & $\begin{array}{l}\text { Quite } \\
\text { reliable }\end{array}$ \\
\hline & 5 & 0.622 & Reliable \\
\hline & 12 & 0.643 & Reliable \\
\hline \multirow[t]{5}{*}{ Interpretation } & 1 & 0.594 & $\begin{array}{l}\text { Quite } \\
\text { reliable }\end{array}$ \\
\hline & 6 & 0.586 & $\begin{array}{l}\text { Quite } \\
\text { reliable }\end{array}$ \\
\hline & 7 & 0.595 & $\begin{array}{l}\text { Quite } \\
\text { reliable }\end{array}$ \\
\hline & 8 & 0.636 & Reliable \\
\hline & 14 & 0.629 & Reliable \\
\hline \multirow[t]{4}{*}{ Extrapolation } & 9 & 0.618 & Reliable \\
\hline & 10 & 0.604 & Reliable \\
\hline & 11 & 0.616 & Reliable \\
\hline & 15 & 0.629 & Reliable \\
\hline \multicolumn{4}{|l|}{ Attitude instrument } \\
\hline \multirow[t]{3}{*}{ Cognitive aspect } & 1 & 0.559 & $\begin{array}{l}\text { Quite } \\
\text { reliable }\end{array}$ \\
\hline & 8 & 0.554 & $\begin{array}{l}\text { Quite } \\
\text { reliable }\end{array}$ \\
\hline & 10 & 0.584 & $\begin{array}{l}\text { Quite } \\
\text { reliable }\end{array}$ \\
\hline \multirow[t]{3}{*}{ Affective aspect } & 2 & 0.539 & $\begin{array}{l}\text { Quite } \\
\text { reliable }\end{array}$ \\
\hline & 3 & 0.555 & $\begin{array}{l}\text { Quite } \\
\text { reliable }\end{array}$ \\
\hline & 5 & 0.569 & $\begin{array}{l}\text { Quite } \\
\text { reliable }\end{array}$ \\
\hline \multirow[t]{4}{*}{ Conative aspect } & 4 & 0.510 & $\begin{array}{l}\text { Quite } \\
\text { reliable }\end{array}$ \\
\hline & 6 & 0.518 & $\begin{array}{l}\text { Quite } \\
\text { reliable }\end{array}$ \\
\hline & 7 & 0.539 & $\begin{array}{l}\text { Quite } \\
\text { reliable }\end{array}$ \\
\hline & 9 & 0.606 & Reliable \\
\hline
\end{tabular}

Although the other items could produce quite self-explanatory results, further tests are still required with more respondents.

Reliability was tested by means of Cronbach's $\alpha$ method, using a mathematical equation to assess measurement reliability level. Reliability test is required to test the consistency of an instrument and ensure its reliability ${ }^{18,19} \mathrm{~A}$ measurement instrument's reliability is determined by the $\alpha$ score yielded. The overall $\alpha$ scores of both the knowledge and attitude instruments were 0.620 (reliable) and 0.565 (quite reliable). The test results showed that, by and large, all the items in the knowledge instrument were reliable and those in the latter were quite reliable.

- Table 5 presents each item's $\alpha$ score in both instruments and the $\alpha$ score when a particular item was deleted. An instrument's reliability can be improved by deleting a less valid item. As shown in the table, deletion of item number 12 item in the translation dimension of the knowledge instrument yielded a new $\alpha$ score of 0.643 . In the attitude instrument, deletion of item number 9 in the conative dimension resulted in a new $\alpha$ score of 0.606 . However, item deletion would necessitate reconsideration of the adequacy of the items in the dimension concerned to make the instrument more representative. ${ }^{19}$

Validity test is needed to assess the accuracy of an instrument in performing its measuring function. In addition, validity refers to the property of an instrument which indicates that the variable measured is precisely the variable it is designed to measure. ${ }^{19}$ As shown in - Table 6, the validity of an item is distinguished by its correlation with the total score. The test results revealed that all the items in both instruments were valid. In other words, all the items are feasible for use in measurement.

\section{Conclusion}

Using a basic systematic method and a validity-based approach, we developed instruments to measure maternal knowledge and attitude about the maintenance of dental health in children under three. The knowledge and attitude instruments are each a three-dimensional instrument whose purpose is to reflect important elements of maternal' perspectives concerning the maintenance of their under 3-year-old children's oral health. The instruments are now applicable for use.

Table 6 Pearson's correlation test results

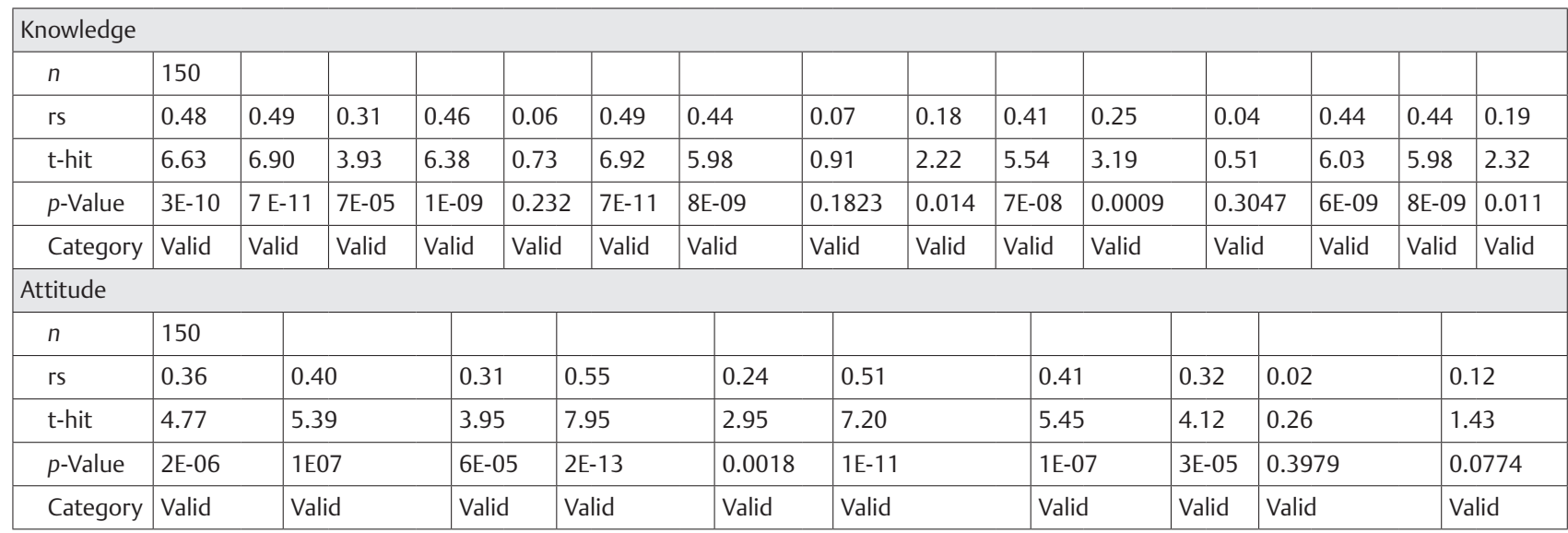




\section{Funding}

This study was funded by the Universitas Padjadjaran Academic Leadership Grant 2020.

\section{Conflict of Interest}

None declared.

\section{References}

1 Setiawan AS, Kendhawati L, Agustiani H. Relational model between parental dental belief and formation of dental fear among preschool children in Indonesia. Eur J Dent 2019;13(3):426-431

2 Setiawan AS, Zubaedah C. Application of health belief model on child's dental visit postponement during the covid-19 pandemic. Eur J Dent 2020;14(S 01) :S7-S13

3 Setiawan AS, Agustiani H, Kendhawati L. Qualitative study on parental behavior as the source of dental fear development as reported by preschool students in Bandung. Eur J Dent 2018;12(4):480-484

4 Clarke R, Shaw-Ridley M. Parental attitudes and beliefs about preschooler preventive oral health behaviors: implications for health promotion. J Immigr Minor Health 2019;21(4):731-736

5 Hooley M, Skouteris H, Boganin C, Satur J, Kilpatrick N. Parental influence and the development of dental caries in children aged 0-6 years: a systematic review of the literature. J Dent 2012;40(11):873-885

6 Bozorgmehr E, Hajizamani A, Malek Mohammadi T. Oral health behavior of parents as a predictor of oral health status of their children. ISRN Dent 2013;2013:741783

7 Heaton B, Crawford A, Garcia RI, et al; Native Oral Health Project. Oral health beliefs, knowledge, and behaviors in Northern California American Indian and Alaska Native mothers regarding early childhood caries. J Public Health Dent 2017;77(4):350-359

8 Sehrawat P, Shivlingesh KK, Gupta B, Anand R, Sharma A, Chaudhry M. Oral health knowledge, awareness and associated practices of pre-school children's mothers in Greater Noida, India. Niger Postgrad Med J 2016;23(3):152-157

9 Begzati A, Bytyci A, Meqa K, Latifi-Xhemajli B, Berisha M. Mothers' behaviours and knowledge related to caries experience of their children. Oral Health Prev Dent 2014;12(2): 133-140

10 Castilho AR, Mialhe FL, Barbosa TdeS, Puppin-Rontani RM. Influence of family environment on children's oral health: a systematic review. J Pediatr (Rio J) 2013;89(2):116-123

11 Abduljalil HS, Abuaffan AH. Knowledge and practice of mothers in relation to dental health of pre-school children. Adv Genet Eng 2016;5(1):7

12 Emadian M, Shafaroudi AM, Mesgarani A, Afkhaminia F, Nahvi A. Mother's knowledge regarding oral health among their preschool children. Int J Pediatr 2020;8(8):11681-11688

13 Mahmoud N, Kowash M, Hussein I. Hassan A, Al Halabi M. Oral health knowledge. attitude. and practices of Sharjah mothers of preschool children. United Arab Emirates. J Int Soc Prev Community Dent 2017;7(6):308-314

14 Gurunathan D, Moses J, Arunachalam SK. Knowledge. attitude. and practice of mothers regarding oral hygiene of primary School children in Chennai. Tamil Nadu. India. Int J Clin Pediatr Dent 2018;11(4):338-343

15 Mehmood R, Rasheed S, Ijaz M. Knowledge. attitude. and practice regarding oral health among secondary school students of Azad Kashmir. Pakistan. Pak J Public Health 2018;8(1):32-36

16 Adesoji FA. Bloom taxonomy of educational objectives and the modification of cognitive levels. Adv Soc Sci Res J 2018;5(5):292-297

17 Huang YM, Lou SJ, Huang TC, Jeng YL. Middle-aged adults' attitudes toward health app usage: a comparison with the cognitive-affective-conative model. Univers Access Inf Soc 2019;18:927-938

18 Anunciação L. An overview of the history and methodological aspects of psychometrics. J Reatt Ther Dev Divers 2018;1(1):44-58. Doi:10.26407/2018jrtdd.1.6

19 Souza AC, Alexandre NMC, Guirardello EB. Psychometric properties in instruments evaluation of reliability and validity. Epidemiol Serv Saude 2017;26(3):649-659

20 Namjoo S, Shaghaghi A, Sarbaksh P, Allahverdipour H, Pakpour AH. Psychometric properties of the General Health Questionnaire (GHQ-12) to be applied for the Iranian elder population. Aging Ment Health 2017;21(10):1047-1051 